\title{
The Effect of Role Ambiguity and Time Pressure on Job Performance among Employees at Water Supply Services Company in Malaysia
}

Nurhafizah Mohd Zolkapli, Nor Maslia Rasli Samudin, Siti Nurul Akma Ahmad, Siti Norashikin Bashirun, Farah Shazlin Johari, Nur Idayu Badrolhisam

To Link this Article: http://dx.doi.org/10.6007/IJARBSS/v12-i1/11286

DOI:10.6007/IJARBSS/v12-i1/11286

Received: 07 November 2021, Revised: 11 December 2021, Accepted: 28 December 2021

Published Online: 15 January 2022

In-Text Citation: (Zolkapli et al., 2022)

To Cite this Article: Zolkapli, N. M., Samudin, N. M. R., Ahmad, S. N. A., Bashirun, S. N., Johari, F. S., \& Badrolhisam, N. I. (2022). The Effect of Role Ambiguity and Time Pressure on Job Performance among Employees at Water Supply Services Company in Malaysia. International Journal of Academic Research in Business and Social Sciences, 12(1), $750-761$.

\section{Copyright: (c) 2022 The Author(s)}

Published by Human Resource Management Academic Research Society (www.hrmars.com) This article is published under the Creative Commons Attribution (CC BY 4.0) license. Anyone may reproduce, distribute, translate and create derivative works of this article (for both commercial and non0-commercial purposes), subject to full attribution to the original publication and authors. The full terms of this license may be seen at: http://creativecommons.org/licences/by/4.0/legalcode

$$
\text { Vol. 12, No. 1, 2022, Pg. } 750-761
$$




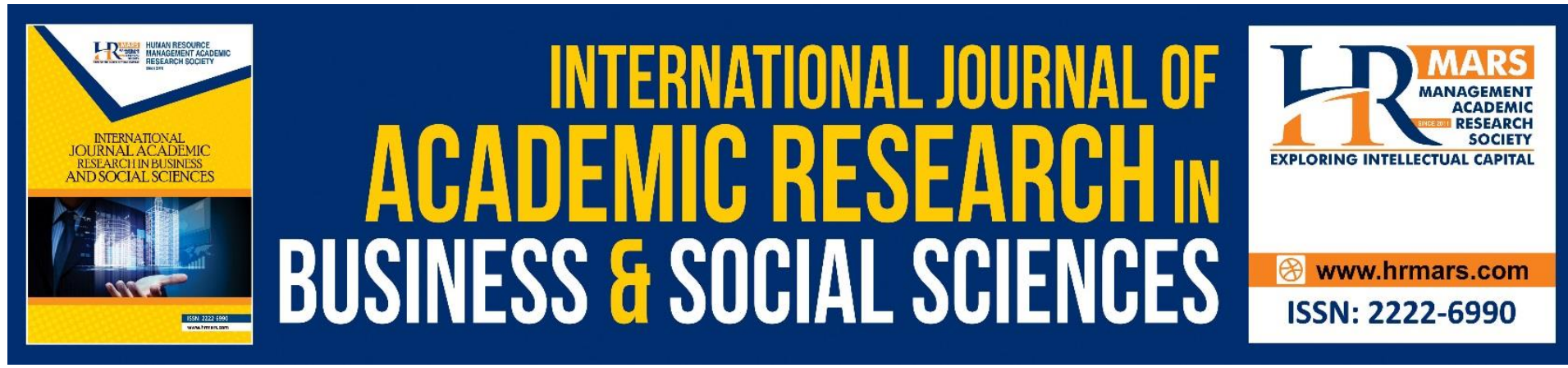

\title{
The Effect of Role Ambiguity and Time Pressure on Job Performance among Employees at Water Supply Services Company in Malaysia
}

\author{
Nurhafizah Mohd Zolkapli, Nor Maslia Rasli Samudin, Siti Nurul \\ Akma Ahmad, Siti Norashikin Bashirun, Farah Shazlin Johari \\ Faculty of Business and Management, Universiti Teknologi MARA, Melaka, Malaysia
}

\author{
Nur Idayu Badrolhisam
}

Faculty of Business and Management, Universiti Teknologi MARA, Puncak Alam, Malaysia

\begin{abstract}
This study explores the effect of job stress's factors, role ambiguity and time pressure on job performance among employees in one of the water supply services companies situated at Muar, Johor, Malaysia. Besides, this study also aims to examine the most influential predictor on job performance among the respective employees. The study chose 144 employees from the respective company conveniently to participate in this study. All questionnaires were returned with complete answers by the respondents. Data had been evaluated through three analyses: descriptive, correlation, and regression analysis using Statistical Package for Social Science (SPSS). The results of the descriptive analysis indicated that the majority of the respondents were male, married and aged between 20 to 30 years old. Besides, most of the respondents have worked with the company for more than 15 years and SPM holders. Based on the correlation analysis, the finding discovered a positive and weak relationship between time pressure and job performance. Nevertheless, the result indicated that role ambiguity has a positive and strong relationship with job performance. Moreover, the study's findings based on regression analysis revealed that job stress factors had an influence of $55.9 \%$ on job performance. Another $44.1 \%$ was conceivably influenced by other variables that were not being studied. Furthermore, it also showed that role ambiguity is the most influenced factor of job stress on job performance. The finding of this study offers several significant insights and information for the company about the importance of job stress and its relationship with the employees' job performance.
\end{abstract}

Keywords: Job Stress, Job Performance, Role Ambiguity, Time Pressure

\section{Introduction}

The performance of an organisation's employees is closely related to its success. Job performance is essential to organisations in this modern era, especially to see if employees can attain their maximum potential and assist the company accomplish their objective. It will be easier for the organisation to achieve its business goals if employees are well informed 
about their job responsibilities. According to Anitha (2014), performance can be defined as keeping up plans while targeting to achieve the desired results.

Excellent job performance can be achieved and contributed to ensuring the organisation meets its objectives and expectations through employees' work and contribution. Organisations are more likely to hire individuals with high performance who can offer them high-quality work and avoid hiring inefficient people. When the organisation sets a high standard of performance for the employee to achieve, it will increase stress levels among them. Job stress is rising among employees, and it's becoming a more significant concern for organisations since it may lead to lower productivity, more absenteeism, and a slew of other employee issues, including drug addiction, alcoholism, anxiety, and cardiovascular problems (Imtiaz \& Ahmad, 2009).

Job-related stress is one of the most severe issues that Malaysian employees encounter (Mallow, 2016). Particularly in service organisations, since the nature of the job itself requires the employee to deal with various customer behaviour types (Azmi et al., 2016). This can be even worse since individuals in the service industry must have positive emotions since they must interact with customers who want to offer high-quality service to satisfy their expectations (Hofmann \& Stokburger-Sauer, 2017). Consequently, the mental and physical wellbeing of those individuals can be jeopardised if the job stress cannot be controllable.

Essentially, various factors negatively influence job performance, such as time pressure and role ambiguity. According to Sharmilee, Abdul, and Zubair (2017), time pressure and role ambiguity have negatively influenced employee performance. Yahaya et al (2009) indicated that employee turnover looks to be excessively high when they are given too many tasks or work assignments and are expected to complete them in a short amount of time. Besides, when dealing with role ambiguity, they face emotional difficulties, a pathological loss of reality, and a significant drop in success (Karatepe and Uludag, 2008). If these job-related stress issues are not adequately addressed, it may be detrimental to both the employee and the organisation.

Thus, based on the background of the study ad problem statement, the objective of this study is to explore the effect of job stress's factors, role ambiguity and time pressure on job performance. Additionally, this study aims to examine the most influential predictor on job performance in one of the water supply services companies situated at Muar, Johor, Malaysia.

\section{Literature Review \\ Job Stress}

Job stress has been defined in different ways over the years. In general, job stress can be defined as a phenomenon that every subordinate and superior experiences and coping with it differently according to a specific approach. It is essentially a misalignment of individual skills and organisational requirements (Pediwal, 2011; Jayashree, 2010). Moreover, job stress is an unpleasant emotional state that happens when the job demands outweigh a person's ability to deal with the circumstance. It is a familiar phenomenon that manifests differently in different work contexts and affects employees (Malek, 2010). Due to stress, an individual's expectations of the organisation and his demands become distorted. Job stress has now evolved into a worldwide issue that affects all countries, all types of employees, and all civilisations (Haider \& Supriya, 2007).

Furthermore, according to Chen and Silverthorne (2008), job stress is a highly personal reaction that varies from general stress in that it is also connected to organisation and work. 
Greenberg and Baron (2007) acknowledged that job stress could be a group of external destructive factors in the work atmosphere, physical, psychological, or social. Additionally, job stress significantly influences employees' performance and productivity (Mimura \& Griffiths, 2003).

Numerous studies have been conducted by prior researchers in identifying factors of job stress. Based on the research undertaken by Murali (2017), two contributing factors of job stress which includes time pressure and role ambiguity had been identified and studied by the researchers.

According to role theory, role ambiguity is the lack of definition and predictability in an employee's job or role duties and responsibilities (Kahn et al., 1964; Beehr, 1976). Kalbers and Cenker (2008) mentioned that role ambiguity is an employee's lack of confidence in understanding their job. Role ambiguity can also occur when individuals are forced to do many different tasks at once (Harijanto et al., 2013). Besides, lack of precise information causes role ambiguity, which is a job stressor (Larson, 2004). Based on the role theory explained by Kahn et al. (1964), when a job holder's function is unclear, they will engage in coping behaviour to solve unknown duties and relieve stress, misrepresent the reality of the job's requirements.

Individuals are frequently forced to finish increasing daily responsibilities in a short amount of time, which has become a natural aspect of the environment. Time pressure is defined as reducing the amount of time available to perform a task (Klapproth, 2008). When time pressure is minimal, it can lead to fatigue and a lack of energy, interfering with job duties. Furthermore, excessive amounts of time pressure might cause behaviour avoidance and detrimental effect (Gevers, Van Eerde, \& Rutte, 2001). On the other hand, when time pressure is regarded as a very high level, individuals might be impacted by stress (Van Yperen \& Hagedoorn, 2003).

\section{Job Performance}

Job performance refers to all of an employee's attitudes and behaviours that contribute to attaining the organisation's goals (Demirer, 2019). The idea of job performance, which describes to what extent the intended task is performed from an individual perspective, is the sum of the behaviours displayed by the employee to contribute to the organisation's efforts to achieve its objectives (Tekin \& Deniz, 2019). According to Keshin and Gundogan (2019), job performance can be referred to as all employees' actions at work.

Performance is linked to the quality of the approach that workers use to do their job. Employees who lack the necessary knowledge, skills, and competencies for the position will be more stressed, and their performance may decrease due to their loss of motivation (Altindag, 2020). Meydan et al (2018) described that employees' attempts to attain workrelated objectives are called job performance, a component of task and contextual performance.

Besides, according to Bin (2015), job performance is defined as an employee's capacity to meet corporate objectives and requirements. The concept of job performance is linked to the presence of features (capacity) suited for the job requirements, the employee's desire to do their job (willingness), and the presence of environmental components for the task realisation (Koca \& Yıldız, 2018). Employees exhibit their capacity and desire in line with their job descriptions and duties and get support from the business environment; all contribute to job performance, which is critical to achieving the organisation's goals and objectives (Altindag, 2020). 


\section{Relationship between Factors of Job Stress and Job Performance}

Numerous studies have shown that job stress has a detrimental impact on employee performance, considering the different aspects involved, including employee job satisfaction. For example, a study conducted by Ahmed and Ramzan (2013) has established a negative association between job stress and employee performance. However, Jamal (2007) revealed that the individual faces optimal challenge and his performance would be increased accordingly when stress is at a high level.

According to an earlier study conducted in 2017, role ambiguity has a negative and significant influence on employee performance. Employees' productivity and contribution will decrease if they are unsure of their function and job description in the organisation (Sharmilee, Abdul \& Zubair, 2017). At the same time, previous studies conducted by Murkherjee and Maholtra (2006); Lang et al (2007) found that role ambiguity affects employees' job performance in a service setting. Besides, researchers have found role ambiguity to be associated with a lack of information on goals, conditions in which the job is to be performed, responsibilities, and duties to achieve one's job effectively (Yun, Takeuchi, \& Liu, 2007; Burney \& Widener, 2007; Marginson, 2006).

In most emerging countries, time pressure is becoming a significant issue (Moore \& Tenney, 2012). Time constraints may not have to be viewed or interpreted negatively. However, when time constraints hamper employees' effectiveness, they are more likely to make mistakes (Johnson et al., 1993). According to Lee (2012), a steep rise in time deadline pressure causes performance to drop. Likewise, Broberg et al (2017); Abuaddous et al (2015) found the exact outcome of time pressure negatively impacted performance. Nevertheless, these results contradict Sacramento et al (2013); Wijaya and Yulyona (2017) findings, which found that time pressure did not affect job performance.

Hypotheses to investigate the link between the variables have been established per the above literature review and discussion:

$\mathrm{H}_{1}$ : There is a significant relationship between role ambiguity and job performance.

$\mathrm{H}_{2}$ : There is a significant relationship between time pressure and job performance.

\section{Methodology}

The study was purposely conducted to examine the effect of job stress's factors (role ambiguity and time pressure) on job performance and explore the most influential predictor of job performance. To perform this study, the convenience sampling technique was applied in distributing the questionnaire to the respondents. The survey has been carried out online using Google Form in obtaining the responses from the respondents. All registered employees at one water supply services company situated at Muar, Johor, Malaysia, who worked in several different departments was used as a sampling frame.

The entire population for this study was 228 employees. However, the ideal sample size for this study was 144 employees identified primarily by referring to the Krejcie and Morgan's table. A five-point Likert-based scale was used in representing the most suitable answer from the respondents. The description of the Likert scales includes 1-Strongly Disagree, 2-Disagree, 3-Neutral, 4-Agree, and 5-Strongly Agree.

The Statistical Package for Social Science (SPSS) 22.0 was applied to evaluate data through three analyses in this study. First, a descriptive analysis was initially performed to generate descriptive gender, age, race, marital status and educational level. Second, a correlation 
analysis was applied to examine the relationship between job stress's factors (role ambiguity and time pressure) and job performance. Finally, regression was the third analysis used to identify the most influential predictor among job stress and job performance factors.

\section{Reliability}

Reliability relates to the consistency of a measure (Heale \& Twycross, 2015). According to Sarasvathy (2013) reliability test had been used to measure the instrument's accuracy in which the respondents can provide the same answer to the same question each time. In analysing the reliability of the questionnaire, Cronbach's Alpha values were used to measure the internal consistency and level of strength of each variable that is available in this study. In testing the reliability of the questionnaires' answers, reliability analysis was conducted by referring to the rule of thumb made by Hair et al (2003). They described that Cronbach's Alpha $(\alpha)$ values of 0.9 and above shows excellent reliability, 0.8 to $<0.9$ shows very good reliability, 0.7 to $<0.8$ shows good reliability, 0.6 to $<0.7$ shows moderate reliability and $<0.6$ shows poor reliability.

Based on Table 1, the result of reliability analysis was indicated that Time Pressure's variable (0.767) have good consistency with Cronbach's Alpha value. In contrast, variables of Role Ambiguity (0.878) and Job Performance $(0.881)$ have very good consistency with Cronbach's Alpha value. Therefore, these values are adequate to confirm its reliability, as what Hair et al. (2003) discussed in their studies.

Table 1. Result of Reliability Analysis

\begin{tabular}{lll}
\hline NO. & CONSTRUCT & CRONBACH'S ALPHA VALUE \\
\hline 1. & Role Ambiguity (Independent Variable) & 0.878 \\
2. & Time Pressure (Independent Variable) & 0.767 \\
3. & Job Performance (Dependent Variable) & 0.881 \\
\hline
\end{tabular}

\section{Finding}

\section{Descriptive Analysis}

From all 144 questionnaires distributed by the researchers, all respondents have successfully answered the valid questionnaires. Therefore, this study represented employees from one of the water supply services companies located at Muar, Johor, Malaysia. Based on Table 2, the majority of the respondents were male $(n=94,65.3 \%)$ and aged between 20-30 years old $(n=44,30.6 \%)$. Further, most of the respondents have been working with the company for more than 15 years $(n=61,42.4 \%)$. Moreover, majority of the respondents were married $(n=104,72.2 \%)$ and SPM holders $(n=58,40.3 \%)$. 
Table 2. Demographic Background

\begin{tabular}{lll}
\hline & FREQUENCY (f) & PERCENT (\%) \\
\hline Gender & 94 & 65.3 \\
$\quad$ Male & 50 & 34.7 \\
$\quad$ Female & & \\
\hline Age & 44 & 30.6 \\
20-30 years old & 33 & 22.9 \\
31-40 years old & 30 & 20.8 \\
41-50 years old & 37 & 25.7 \\
51 years old and above & & \\
\hline Working Tenure & 44 & 30.6 \\
Less than 5 years & 18 & 12.5 \\
6-10 years & 21 & 14.6 \\
11-15 years & 61 & 42.4 \\
More than 15 years & & \\
Marital Status & 104 & 72.2 \\
Married & 36 & 25.0 \\
Single & 4 & 2.8 \\
Others & & \\
\hline Educational Level & 58 & 40.3 \\
SPM & 14 & 9.7 \\
STPM & 40 & 27.8 \\
Diploma & 30 & 20.8 \\
Degree & 2 & 1.4 \\
Master & & \\
\hline
\end{tabular}

\section{Correlation Analysis}

In examining the relationship between job stress factors (role ambiguity and time pressure) and job performance in this study, Strength of Correlation Interpretation guidelines by Salkind (2012) were referred to interpret the results. Hence, the results available in the Table 3 revealed a weak and significant relationship between time pressure and job performance $(r=0.343, p<0.01)$. However, a solid and significant relationship existed between role ambiguity and job performance $(r=0.745, p<0.01)$. From the results, both factors of job stress had shown a significant relationship with job performance. Thus, all the research hypotheses that have been constructed earlier were accepted.

Table 3. Correlations Table for Factors of Job Stress and Job Performance

\begin{tabular}{l|l|l|l}
\hline & & Time Pressure & Role Ambiguity \\
\hline \multirow{3}{*}{ Job Performance } & $\begin{array}{l}\text { Pearson } \\
\text { Correlation }\end{array}$ & $.343^{* *}$ & $.745^{* *}$ \\
\cline { 2 - 4 } & $\begin{array}{l}\text { Sig. } \\
(2 \text {-tailed })\end{array}$ & 0.00 & 0.00 \\
\cline { 2 - 4 } & $\mathrm{N}$ & 144 & 144 \\
\hline
\end{tabular}

\section{Regression Analysis}

In this study, multiple regression analysis was performed to identify how well the independent variables predict the value of the dependent variable. Based on the results that available in Table 4, the development of $\mathrm{R}$ Square was $55.9 \%$. This indicated that the 
independent variables, which are factors of job stress (role ambiguity and time pressure), influenced $55.9 \%$ towards the dependent variable (job performance). In contrast, another $44.1 \%$ of the independent variables were not influencing the dependent variable and were replaced by other variables. This depicted that $55.9 \%$ of job performance at selected water supply services companies can be explained by job stress factors that consist of role ambiguity and time pressure.

Table 5 shows the regression results of the association between factors of job stress and job performance. Based on the result available in the table, it could be seen that role ambiguity is the most influenced factor on job performance, with a beta value of 0.720 . On the other hand, time pressure also influenced job performance with a beta value $(0.065)$ that was slightly lower compared to role ambiguity. Table 5 also showed that role ambiguity is a significant variable because its $p$-value is below 0.01 . However, the $p$-value for time pressure is greater than 0.05 , signifying that the result is not statistically significant.

Table 4. Model Summary

\begin{tabular}{l|l|l|l|l|l} 
Model & $\mathbf{R}$ & R Square & $\begin{array}{l}\text { Adjusted } \\
\text { Square }\end{array}$ & $\mathbf{R}$ & $\begin{array}{l}\text { Std. Error of the } \\
\text { Estimate }\end{array}$ \\
\hline 1 & $.747^{\mathrm{a}}$ & .559 & .552 & .33187 \\
\hline
\end{tabular}

a. Predictors: (Constant), Role Ambiguity, Time Pressure

b. Dependent Variable: Job Performance

Table 5. Results of Regression Analysis

\begin{tabular}{|c|c|c|c|c|c|}
\hline \multicolumn{6}{|l|}{ Coefficients } \\
\hline \multirow[t]{2}{*}{ Model } & \multicolumn{2}{|c|}{$\begin{array}{l}\text { UnstandardizedUnstandardis } \\
\text { ed Coefficients }\end{array}$} & \multirow{2}{*}{$\begin{array}{l}\text { StandardizedStandardis } \\
\text { ed Coefficients } \\
\text { Beta }\end{array}$} & \multirow[t]{2}{*}{$\mathbf{t}$} & \multirow[t]{2}{*}{ Sig. } \\
\hline & B & Std. Error & & & \\
\hline \multirow{3}{*}{$\begin{array}{l}1 \text { (Constant) } \\
\text { Time } \\
\text { Pressure } \\
\text { Role } \\
\text { Ambiguity }\end{array}$} & 1.066 & .259 & & 4.119 & $\begin{array}{l}<.00 \\
1\end{array}$ \\
\hline & .051 & .048 & .065 & 1.068 & .287 \\
\hline & .719 & .061 & .720 & $\begin{array}{l}11.86 \\
8\end{array}$ & $\begin{array}{l}<.00 \\
1\end{array}$ \\
\hline
\end{tabular}

a. Dependent Variable: Job Performance

\section{Conclusion and Recommendations}

The main objective of this study examines the effect of job stress's factors, role ambiguity and time pressure on job performance. The finding signified that role ambiguity and time pressure have a significant relationship with job performance among employees at one of the supply service companies at Muar, Johor, Malaysia. Furthermore, the study's result indicated a weak significant relationship between time pressure and job performance $(r .=0.343, p<0.01)$. However, the result revealed that role ambiguity has a significant relationship between role ambiguity and job performance $(r=0.745, p<0.01)$. Moreover, the study discovered that role ambiguity is the most influential predictor that leads to job performance among employees at the respective company with the highest beta value $(\beta=0.720, p<0.01)$. On the result of the study, it can be concluded that both factors of job stress, which are role ambiguity and time pressure, significantly influenced job performance, supporting the constructed hypotheses. The finding of hypothesis 1 was consistent with several past researches that revealed the role ambiguity as to the factor that significantly influences employees' job performance (Sigh, 
1993; Bhuian et al., 2005; Chang \& Chang, 2007). In addition, for hypothesis 2, the finding was similar to the study conducted by Sharmilee et al (2017), who also revealed the significant relationship between time pressure and job performance.

Since the understanding and awareness about factors of job stress which are role ambiguity and time pressure are essential, thus, several recommendations have been suggested to control their impact on the job performance of the employees in the organisation. First, to solve the problem related to role ambiguity in the workplace, the management should give a clear job description and instruction for each role and provide the employee with a clear set of expectations, objectives and deadlines. Second, in improving the issues related to time pressure, it is suggested that the management ensure they give sufficient time for the employee to complete their job. Although some superiors perceive time pressure as motivating employees to deliver better performance, they should pay extra attention to the impact of time pressure on employee wellbeing, especially their mental health condition.

\section{Limitations and Future Work}

This study has some limitations and offers potential areas for future research. One of the limitations of this study is that the sample size of the survey conducted was considered small compared to other prior studies that several scholars had performed. Moreover, this study has mainly focused on water supply services company at Muar, Johor, Malaysia. Thus, the generalizability of the results should be further established through studies that can be performed across different employment sectors. Besides, the study only considered two job stress factors: role ambiguity and time pressure, as the predictors of job performance. Therefore, for future research, it is recommended that the researchers further investigate other factors of job stress such as job insecurity, heavy workload, lack of empowerment, role conflict, or discrimination that could impact job performance among the employees.

\section{Acknowledgement}

The authors want to thank all of the employees who took the time to complete the survey. The authors also like to thank everyone who helped them stay motivated to finish the study, whether directly or indirectly.

\section{Corresponding Author}

Nurhafizah binti Mohd Zolkapli

Faculty of Business and Management, Universiti Teknologi MARA, Melaka

Email: nurhafizahzolkapli@uitm.edu.my

\section{References}

Abuaddous, M., Hanefah, M. M., \& Laili, N. H. (2014). Accounting Standards, Goodwill Impairment And Earnings Management In Malaysia. International Journal of Economics and Finance, 6(12), 201-211.

Ahmed, A., \& Ramzan, M. (2013). Effects of Job Stress on Employees Job Performance: A Study on Banking Sector of Pakistan. IOSR Journal of Business and Management, 11(6), 61-68.

Altindag, O. (2020). Relationship Between Stress Management and Job Performance in Organizations. International Journal of Research In Business and Social Science, 9(2), 4349. 
Anitha, J. (2014). Determinants of Employee Engagement and Their Impact on Employee Performance. International Journal of Productivity and Performance Management, 63(3), 308-323.

Azmi, F. S., Md. Shahid, S. A., \& Alwi, A. (2016). The Relationship between Job Stress and Front-liners Performance in a Shared Service Center in Malaysia. International Journal of Social Science and Humanity, 6(7), 510-513.

Beehr, T. A. (1976). Perceived Situational Moderators of The Relation Between Subjective Role Ambiguity and Role Strain. J. Appl. Psychol., 61: 35-40.

Bhuian, S. N., Menguc, B. \& Borsboom, R. (2005). Stressors and Job Outcomes in Sales: A Triphasic Model versus a Linear-Quadratic_Interactive Model. Journal of Business Research, 58, 141-150.

Bin, A. S. (2015). The Relationship Between Job Satisfaction, Job Performance And Employee Engagement: An Explorative Study. Issues in Business Management And Economics, 4(1), 1-8.

Broberg, P., Tagesson, T., Argento, D., Gyllegnahm, N., and Martensson, O. (2017). Explaining the Influence of Time Budget Pressure on Audit Quality in Sweden. Journal of Management and Governance, 21 (2).

Burney, L., \& Widener, S. K. (2007). Strategic Performance Measurement Systems, Job Relevant Information, and Managerial Behavioural Responses - Role Stress and Performance. Behavioral Research in Accounting, 19(1), 43-69.

Chang, T. Y., \& Chang, Y. L. (2007). Relationship Between Role Stress And Job Performance In Sales people Employed By Travel Agents In Taiwan. International Journal of Stress Management, 14, 211-223.

Chen, J., \& Silverthorne, C. (2008). The Impact of Locus of Control on Job Stress, Job Performance and Job Satisfaction in Taiwan. Leadership \& Organization, Development Journal, 29(7), 572-582.

Gevers, J. M. P., Van Eerde, W., \& Rutte, C. G. (2001). Time Pressure, Potency, and Progress in Project Groups. European Journal of Work \& Organizational Psychology, 10, 205-221.

Greenberg, J., \& Baron, R. A. (2007), Behavior in OrganizationsOrganisations: Understanding and Meaning the Human Side Of Work, Prentice Hall.

Haider, Y., \& Supriya, M. V. (2007). Career Management: A View Through Stress Window. International Review of Business Research Papers, 3(5), 182-192.

Hair, J., Babin, B., Money, A., and Samouel, P. (2003) 'Essentials of Business Research Methods', New York: John Wiley and Sons Inc.

Harijanto, D., Nimran, U., Sudiro, A., \& Rahayu, M. (2013). The Influence of Role Conflict and Role Ambiguity on The Employee's Performance Through Commitment and Self Efficacy (Study on Nurses at Public Health Service Center of Kabupaten Kediri, East Java. IOSR Journal of Business and Management, 98-105.

Heale, R., \& Twycross, A. (2015). Validity and Reliability in Quantitative Studies. EvidenceBased Nursing, 18(3), 66-67.

Hofmann, V., \& Stokburger-Sauer, N. E. (2017). The Impact of Emotional Labor on Employees' Work-Life Balance Perception and Commitment: A Study In The Hospitality Industry. International Journal of Hospitality Management, 65, 47-58.

Imtiaz, S., \& Ahmad, S. (2009). Impact of Stress on Employee Productivity, Performance and Turnover; An Important Managerial Issue. International Review of Business Research Papers, 468-477. 
Jamal, M. (2007). Job Stress And Job Performance Controversy Revisited: An Empirical Examination In Two Countries. International Journal of Stress Management, 14(2), 175187.

Jayashree, R. (2010). Stress Management with Special Reference to Public Sector Bank Employees in Chennai. International Journal of Enterprise and Innovation Management Studies, 1(3), 34-39.

Johnson, E. J., Payne, J. W., \& Bettman, J. R. (1993). Adapting to Time Constraints. In O. Svenson \& A. J. Maule (Eds.), Time Pressure and Stress in Human Judgment and Decision Making (pp. 103-116). New York, NY, USA: Plenum Press.

Kahn R. L., Wolfe D. M., Quinn, R. P., Snoek, J. D., Rosenthal, R. A. (1964). OrganizationalOrganisational Stress: Studies in Role Conflict and Ambiguity. New York: Wiley.

Kalbers, L. P., \& Cenker, W. J. (2008). The Impact of Exercised Responsibility, Experience, Autonomy, and Role Ambiguity on Job Performance in Public Accounting. Journal of Managerial Issues, 20 (3), 327-347.

Karatepe, O. M., \& Uludag, O. (2008). Role Stress, Burnout and Their Effects on Frontline Hotel Employees' Job Performance. International Journal of Tourism Research, 10(2), 111126.

Klapproth, F. (2008). Time And Decision Making In Humans. Cognitive, Affective, \& Behavioral Neuroscience, 8(4), 509-524.

Koca, S., \& Yıldız, S. M. (2018). An Investigation OfRelationships Among Stress Resources Of Football Referees, Job Satisfaction And Job Performance. Spor Bilimleri Araştırmaları Dergisi, 3(2), 195-207.

Lang, J., Thomas, J. L., Bliese, P. D., \& Adler, A. B. (2007). Job demands and job performance: the mediating effect of psychological and physical strain and the moderating effect of role clarity. Journal of Occupational Health Psychology, 12(2), 116-124.

Larson, L. L. (2004). Internal Auditors and Job Stress. Managerial Auditing Journal, 19(9), 11191130.

Lee, H. (2012). Incentive Contracts and Time Pressure on Audit Judgment Performance. Managerial Auditing Journal, 27(3), 263-283.

Malek, M. H. B. A. (2010). The Impact of Job Stress on Job Satisfaction among University Staff: Case Study at Jabatan Pembangunan, University of Sains Malaysia Pulau Pinang, 1-89.

Mallow, M. Z. (2016). Occupational Stress in Malaysia: Causes, Effects \& Possible Solutions. Proceedings of SOCIOINT 2016 3rd International Conference on Education, Social Sciences and Humanities.

Marginson, D. (2006). Information Processing and Management Control: A Note Exploring The Role Played by Information Media in Reducing Role Ambiguity. Management Accounting Research, 17, 187-197.

Meydan, C. H., Dirik, D., \& Eryılmaz, I. (2018). The Moderating Role of Pelz Effect In The Relationship Between Leader Power Sources and Job Satisfaction. Yönetim Ve Ekonomi: Celal Bayar Üniversitesi İktisadi Ve İdari Bilimler Fakültesi Dergisi, 25(1), 75-92.

Mimura, C., \& Griffiths, P. (2003). The Effectiveness of Current Approaches to Workplace Stress Management in the Nursing Profession: An Evidence Based Literature Review. Occupational and Environmental Medicine, 60, 10-15.

Moore, D. A., and Tenney, E. R. (2012), "Time Pressure, Performance, and Productivity", Neale, M.A. and Mannix, E.A. (Ed.) Looking Back, Moving Forward: A Review of Group 
and Team-Based Research (Research on Managing Groups and Teams, Vol. 15), Emerald Group Publishing Limited, Bingley, pp. 305-326.

Mukherjee, A., \& Maholtra, N. (2006). Does Role Clarity Explain Employee-Perceived Service Quality? A Study of Antecedents and Consequences In Call Centres. International Journal of Service Industry Management, 17 (5), 444-473.

Murali, B. S., Basit, A., \& Hassan, Z. (2017). Impact of Job Stress on Employee Performance. International Journal of Accounting \& Business Management, 5(2), 13-33.

Pediwal, G. L. (2010). Excessive Stress and its Impact on Employee Behavior. Journal of Global Economy, 1(1), 13-40.

Sacramento, C. A., Fay, D., \& West, M. A. (2013). Workplace Duties Or Opportunities? Challenge Stressors, Regulatory Focus, And Creativity. Organ. Behav. Hum. Decis. Process., 121, 141-157.

Sarasvathy, M. (2013). Identifying Factors that Influences Job Perfomance amongst Employees in Oil Palm Plantation. Faculty of Applied Social Sciences, Open University Malaysia, 33.

Sharmilee, B. M., Abdul, B., \& Zubair, H. (2017). Impact of Job Stress on Employee Performance. International Journal of Accounting \& Business Management, 5(2), 13-33.

Singh, J. (1993). Boundary role ambiguity: Facets, Determinants, and Impacts. Journal of Marketing, 57, 11-31.

Van Yperen, N. W., \& Hagedoorn, M. (2003). Do High Job Demands Increase Intrinsic Motivation or Fatigue or Both? The Role of Job Control and Job Social Support. The Academy of Management Journal, 46, 339-348.

Vijayan, M. (2017). Impact of Job Stress on Employees' Job Performance in Aavin, Coimbatore. Journal of Organisation \& Human Behaviour, 6(3), 22-29.

Wijaya, I. A., \& Yulyona, M.T. (2017). Does Complexity Audit Task, Time Deadline Pressure, Obedience Pressure, and Information System Expertise Improve Audit Quality? International Journal of Economics and Financial Issues, 7(3), 398-403.

Yahaya, A., Yahaya, N., Arshad, K., Ismail, J., \& Jaalam, S. (2009). Occupational Stress and Its Effects Towards The Organisation Management. Journal of Social Sciences, 5(4), 390397.

Yun, S., Takeuchi, R., \& Liu, W. (2007). Employee Self-Enhancement Motives and Job Performance Behaviors: Investigating The Moderating Effects of Employee Role Ambiguity and Managerial Perceptions of Employee Commitment. Journal of Applied Psychology, 92(3), 745-756. 